\title{
Reducing Diesel Engine Emission using Reactivity Controlled Approach
}

\author{
Osama H. Ghazal' \\ 1 Department of Mechanical Engineering, Applied Science Private University, Amman, Jordan, e-mail: \\ o_ghazal@asu.edu.jo
}

\begin{abstract}
Several automobile manufacturers are interested in investigating of dual fuel internal combustion engines, due to high efficiency and low emissions. Many alternative fuels have been used in dual fuel mode for IC engine, such as methane, hydrogen, and natural gas. In the present study, a reactivity controlled compression ignition (RCCI) engine using gasoline/diesel (G/D) dual fuel has been investigated. The effect of mixing gasoline with diesel fuel on combustion characteristic, engine performance and emissions has been studied. The gasoline was injected in the engine intake port, to produce a homogeneous mixture with air. The diesel fuel was injected directly to the combustion chamber during compression stroke to initiate the combustion process. A direct injection compression ignition engine has been built and simulated using ANSYS Forte professional code. The gasoline amount in the simulation varied from (50\%-80\%) by volume. The diesel fuel was injected to the cylinder in two stages. The model has been validated and calibrated for neat diesel fuel using available data from the literature. The results show that the heat release rate and the cylinder pressure increased when the amount of added gasoline is between 50\%- $60 \%$ volume of the total injected fuels, compared to the neat diesel fuel. Further addition of gasoline will have a contrary effect. In addition, the combustion duration is extended drastically when the gasoline ratio is higher than $60 \%$ which results in an incomplete combustion. The NO emission decreased drastically as the gasoline ratio increased. Moreover, addition of gasoline to the mixture increased the engine power, thermal efficiency and combustion efficiency compared to neat diesel fuel.
\end{abstract}

Keywords: CFD, dual fuel; RRCI engine; green cars; emissions; diesel engine.

\section{INTRODUCTION}

The internal combustion engine operating on dual fuel has many advantages compared to a conventional engine, including emissions and performance. Many research papers proposed different techniques to improve the diesel engine efficiency. Yokota et al. [1] investigated the combustion characteristics of multiple injections compared to the single injection system both experimentally and theoretically. The simulation results show an improvement in the trade-off relation between NOx emissions and fuel consumption of multiple injection technique. On the other hand, the experimental results show that trade-off relation of multiple injections between NOx emissions and fuel consumption becomes worse than those of the single injection for ordinary injection timing.
Kim et al. [2] studied the effect of a two stage injection (earlier injection and late injection near top dead center) on combustion behavior and engine emissions. The results showed that the two-stage injection can reduce NOx emissions compared to single injection DI diesel engine when the injection timing of the first and main injections is optimized. Puduppakkam et al. [3] investigated the effect of pilot diesel fuel quantity and its injection timing on the performance and emissions of $\mathrm{CI}$ engine operating on natural gas (primary fuel) and diesel fuel (pilot fuel). The pilot diesel fuel quantity and injection timing have a significant influence on the performance and emissions of the engine. The results showed that the increased of the pilot fuel amount accompanied with an increase of its injection timing results in an improvement of the engine efficiency and decreased 
the $\mathrm{CO}$ emissions while increasing the $\mathrm{NO}$ emissions. The homogeneous charge Compression Ignition (HCCI) technique has proposed by several researchers as a good solution to increase the engine efficiency and decrease NO emissions. However, the ignition timing and combustion rate should be controlled to gain the complete benefit from the (HCCI) combustion.

Recently, the compression ignition engine with dual fuel mode has been investigated by many automobile manufacturers using different alternative fuels such as methane, natural gas and gasoline. Ma et al. [4] performed an experimental study on the effect of the direct injection timing and premixed ratio of port injected n-heptane with direct injection diesel fuel for CI engine operating on dual fuel. He concluded that the NOx emissions decreased when the premixed ratio increases up to 0.3 , but it increased for higher premixed ratio. Moreover, the diesel injection timing is a major factor that affects the combustion and emission characteristics. Micklow et al. [5] investigated analytically the performance and emission characteristics of a dual fuel engine at part load. The results showed that a large amount of natural gas is unburned near the cylinder wall at part load. Mattarelli et al. [6] analyzed the combustion process of a 4-cylinder diesel engine, operating in both diesel and dual fuel (Diesel and Natural gas) using Computational Fluid Dynamic (CFD) code. The results showed that dual fuel combustion decreased Soot, $\mathrm{CO}$ and $\mathrm{CO}_{2}$ emissions, but increased NO. Miller Jothi et al. [7] studied the effect of Exhaust Gas Recirculation (EGR) on the diesel engine performance and emissions while operating on LPG. They indicated that using EGR method, the brake thermal efficiency increases by about $2.5 \%$ at part load and, NO concentration could be reduced considerably to about $68 \%$ at full load, as compared to LPG operation without EGR. Rajendra Prasath et al. [8] developed a theoretical model to predict the combustion, performance and emission characteristics of low heat rejection CI engine operated with diesel and biodiesel fuels. The results showed a good agreement with experimental data. Chen et al. [9] investigated the Dimethyl Ether (HCCI) combustion and emissions processes using Computational Fluid Dynamics (CFD) model. They performed the DME HCCI combustion process divided into low temperature reaction high temperature reaction regions. Moreover, the unburned fuel and $\mathrm{CO}$ increased when DME equivalence ratio de- creased. Sezer [10] investigated the diesel engine performance and emissions operating on dimeth$\mathrm{yl}$ ether and diethyl ether as an alternative fuels. He confirmed that dimethyl ether and diethyl ether presented a lower engine performance than diesel fuel due to their lower cylinder temperature and pressure. The emission analysis shows that dimethyl and diethyl ethers produce lower carbon dioxides and higher carbon monoxide and nitrogen oxide compared to diesel fuel. Ghazal [11] investigated the effect of $\mathrm{H}_{2}$ /diesel blend fuel ratio, engine speed, and air/fuel ratio on CI engine performance and emissions. The results showed that the hydrogen concentration between $(30 \%$ $40 \%)$ with $(\mathrm{A} / \mathrm{F})$ ratio range (15-20) improves the engine production power and brake thermal efficiency with a reduction of emissions. The reactivity controlled compression ignition engine (RCCI) which combines two or more fuels with different reactivity (such as diesel and gasoline) is another promising technology to provide low emissions and high engine performance compared to a conventional diesel engine. The gasoline is injected to the engine port and mixed with the intake air to form a homogenous mixture which is introduced to a cylinder. Diesel fuel is injected directly to the cylinder in the compression stroke to initiate the combustion. Then, the cylinder mixture undergoes a multipoint ignition due to the existence of the diesel spray all over the mixture. This will increase the flame speed in the mixture and improve the combustion process [12]. The amount of injected diesel fuel, injection timing and duration, and the initial condition of the air/gasoline mixture are the major factors that affect the combustion efficiency and thus enhance the overall engine performance and emissions. The optimum values of all these parameters for the specific engine operation conditions (speed and load), should be determined using one of the professional computational fluid dynamics (CFD) code to avoid the expensive experimental work and engine prototype building. Moreover, the simulation of the combustion process inside the engine is a very complex process because it is a result of the interaction between many phenomena that occur inside the combustion chamber, such as fuel injection, vaporization, mixing, turbulent motion, ignition, and flame prorogation [6]. The combustion process with details kinetics technique obtained by CFD is essential to better understand the phenomena which occur inside the engine, resulting in the possiblity to optimize the 
engine parameters for drawing the maximum benefit from the dual fuel engine [13]. Kim et al. [14] have investigated the effect of the gasoline ratio, the injection pressure and the intake temperature on the engine performance and emissions. They confirmed that the increased of gasoline percentage in the fuel mixture results in advanced ignition timing and the reduction of NOx emission. In addition, the increased intake air temperature causes the reduction of $\mathrm{HC}$ and $\mathrm{CO}$ emissions. Puduppakkam et al. [15] studied the use of a five-component gasoline surrogate and a one-component diesel surrogate by using CFD model based on detailed chemical kinetics approach to simulate the reactivity controlled compression ignition engine (RCCI). They concluded that as the combustion phasing is retarded, the unburned hydrocarbon and $\mathrm{CO}$ emissions increase for the base case and the net indicated thermal efficiency increased up to $50 \%$. Moreover, the uncertainties in the intake valve closing temperature have a more dominant effect on emissions. Zhang et al. [16] studied the effect of intake air temperature on (HCCI) and emissions for dual fuel engine operating on gasoline and n-heptane. The results of the performed experiments show that as intake air temperature decreases up to 55 ${ }^{\circ} \mathrm{C}$, heat release, peak pressure, un-burnt hydrocarbon and $\mathrm{CO}$ decrease as well. Further decreasing of intake temperature causes instability of the combustion process and misfire happens. Moreover, under fixed intake air temperature conditions, increased gasoline ration in the fuel raised $\mathrm{HC}$ and $\mathrm{CO}$ emission. Lopez et al. [13] investigated the effect of different gasoline and diesel blends ratio on ignition delay and flame structure for diesel engine. The results confirmed that the soot formation is affected by the flame lift-off length which is related to the fuel reactivity. In addition, the ignition delay is increased as the gasoline ration increased in the mixture. Cha et al. [17] studied the effect of gasoline quantity in the fuel mixture and the diesel injection timing on the combustion and emission characteristic for compression ignition engine. The results showed that gasoline addition reduces soot and NO emissions by eliminating the high temperature region in the combustion chamber. Conversely, the $\mathrm{HC}$ and $\mathrm{CO}$ have increased. Banajes et al. [18] investigated experimentally and numerically the (RCCI) mixing-combustion process using gasoline and diesel blend fuels. The results showed that as the gasoline ratio increased in the mixture (up to $25 / 75 \%$ diesel/gasoline ratio), the ignition delay is lengthened and the flame propagation improved, shortening the combustion duration. In addition, RCCI combustion reduces soot and NOx with increasing $\mathrm{HC}$ and $\mathrm{CO}$ emissions, compared to a conventional diesel engine. Han et al. [19] studied the effects of engine compression ratio and fuel mixture proportion on the ignition processes of blends $\mathrm{n}$-heptane and gasoline. The increased gasoline proportion reduces the peak cylinder pressure, retardation in the phasing and extends the ignition delays. Moreover, at a sufficient level of gasoline quantity in the fuel, knock combustion can be avoided. Won et al. [20] investigated the effects of running single cylinder compression ignition engine on three fuels (gasoline, diesel, and gasoline/diesel blend). They found that the fuels with low reactivity produce high $\mathrm{HC}$ and $\mathrm{CO}$ emissions in low load conditions and more difficult ignitions at very high EGR, particularly at high engine speed. However, low smoke and NOx emissions can be achieved by using a large nozzle diameter. Park et al. [21] investigated experimentally the fuel properties, droplet atomization, combustion efficiency, and emission characteristics of gasoline-diesel direct blended fuels in a diesel engine. They found that as gasoline amount increased the fuel density, droplet size, kinematic viscosity, and surface tension decreased. Moreover, the gasoline addition reduces ISNOx and ISsoot and increases ISHC and ISCO emissions. However, the effects of gasoline blending on combustion performance and exhaust emissions diminished as the engine load increased. Yang et al. [22] investigated different dual-fuel combustion modes (gasoline /diesel blend) on diesel engine performance and emissions. Highly Premixed Charge Combustion (HPCC) and (LTC) modes have been performed. Moreover, in the HPCC mode, both early-injection (E-HPCC) and late-injection (L-HPCC) of diesel have been used. The results showed that the heat release rate and maximum pressure rise rate values for the (EHPCC) are comparable to the (L-HPCC) values. On the other and, the lowest $\mathrm{NO}_{\mathrm{x}}$ emission was predicted for (EHPCC) mode. Chen et al. [23] studied the combustion and emission characteristics of (DMF-diesel, n-butanol-diesel and gasoline-diesel blends) for compression ignition engines. They indicated that under the same CA50 conditions, D30 produce the highest NOx and then followed by G30, B30 and neat diesel. Moreover, D30 has longer ignition delay, faster burn- 
ing rate, peak heat release rate and maximum pressure rise rate compared to other fuels.

In the present work, the effect of gasoline/ diesel $(G / D)$ fuel ratio on $\mathrm{CI}$ engine performance and emissions has been analyzed. A diesel engine model with dual fuel (gasoline/diesel) has been built and simulated using the ANSYS Forte code with details chemical kinetics technique to solve the injection, evaporation, mixing, and combustion process during engine cycle. The gasoline has been injected to the engine port to create a homogeneous air/fuel mixture which undergoes a compression process inside the cylinder. Then, the diesel fuel has been injected in two stages during compression stroke to initiate the combustion. The total amount of injected fuel (gasoline and diesel) was kept constant and equal 130 [mg] during all the simulation tests. The gasoline/diesel fuel ratio has been changed from (50-80\%) by volume. The engine speed was kept constant (1300 rpm). The model has been validated using available experiment data in the literature for neat diesel engine operation. A good correlation between the experimental and simulation data has been shown. The final conclusions about the effect of adding gasoline to diesel fuel are fully discussed.

\section{CFD MODEL}

In this investigation, the professional ANSYS Forte CFD Package is used. This program is designed for an internal combustion engine to solve the basic governing equations and combustion process using the chemical kinetics technique to provide the most accurate solutions possible for these applications [24]. The brief descriptions of the sub-models used in the simulation are illustrated in Table 1. A single cylinder 4-stroke compression ignition engine with port and direct fuel injection has been built using ANSYS Forte code. This enables the investigation of "the effect of adding gasoline to direct injection compression ignition engine" on performance and emissions. The gasoline fuel was injected in the engine intake port and the diesel fuel was injected directly in the cylinder during the compression stroke in two stages. The gasoline/diesel ratio was varied between $(50 \%$ and $80 \%)$ by volume. The iso-octane and n-heptane were used as surrogate fuels in the simulation for gasoline and diesel, respectively; for simplicity, iso-octane and n-heptane will be called as gasoline and diesel during the analysis. The properties of gasoline, diesel, $n$-heptane, isooctane fuels are presented in Table 2. This study uses a $60^{\circ}$ sector mesh of the combustion chamber to reduce the calculation time as shown in Fig. 1. The engine speed for all simulation tests is kept at $1300[\mathrm{rpm}]$. The tests were conducted taking into account the system behavior from intake valve closure (IVC) to exhaust valve opening (EVO). The total amount of injected fuel (gasoline + diesel) was kept constant 130 [mg/per cycle] for all tests. The injection angles for diesel fuel were kept constant for all tests. Two-stage diesel injection technique is used. The in-cylinder pressure and temperature, heat release rate, $\mathrm{CO}, \mathrm{NOx}$, and un-burnt hydrocarbon have calculated for different fuel ratios and compared with neat diesel fuel. Moreover, the engine power, thermal efficiency,

Table 1. Simulation sub-models

\begin{tabular}{|l|l|}
\hline Turbulence model & RNG k-epsilon \\
\hline $\begin{array}{l}\text { Flame speed } \\
\text { model }\end{array}$ & Power Law Formulation \\
\hline $\begin{array}{l}\text { Droplet collision } \\
\text { model }\end{array}$ & Radius of Influence Model \\
\hline $\begin{array}{l}\text { Spray initialization } \\
\text { model }\end{array}$ & $\begin{array}{l}\text { Constant Discharge Coefficient and } \\
\text { Angle }\end{array}$ \\
\hline Breakup model & $\begin{array}{l}\text { Kelvin-Helmholtz / Rayleigh-Taylor } \\
\text { (KH/RT) }\end{array}$ \\
\hline Collision model & O'Rourke and Amsden \\
\hline $\begin{array}{l}\text { Droplet } \\
\text { vaporization model }\end{array}$ & $\begin{array}{l}\text { discrete multi-component (DMC) fuel- } \\
\text { vaporization model }\end{array}$ \\
\hline $\begin{array}{l}\text { Basic fluid } \\
\text { dynamics model }\end{array}$ & Navier-Stokes equations \\
\hline Wall Model & Law of the Wall. \\
\hline
\end{tabular}

Table 2. Properties of diesel and gasoline fuel [4, 21]

\begin{tabular}{|l|c|c|c|c|c|}
\hline \multicolumn{1}{|c|}{ Fuel property } & Unit & Diesel & Gasoline & n-heptane & iso-octane \\
\hline Chemical formula & & $\mathrm{C} 10.8 \mathrm{H} 18.7$ & $\mathrm{C} 8 \mathrm{~h} 18$ & $\mathrm{n}-\mathrm{C} 7 \mathrm{H} 16$ & 100.16 \\
\hline Molar mass & $\mathrm{g} / \mathrm{mol}$ & 148.3 & 114.15 & 0.688 & 0.692 \\
\hline density & $\mathrm{g} / \mathrm{cm}^{3}$ & 0.839 & 0.765 & 98 & 99.4 \\
\hline Boiling point & ${ }^{\circ} \mathrm{C}$ & $180-370$ & $27-225$ & 44.5 & 44.651 \\
\hline Lower heat value & $\mathrm{MJ} / \mathrm{kg}$ & 42.9 & 44 & 56 & 14 \\
\hline Cetane number & - & $40-55$ & $5-20$ & & 58 \\
\hline
\end{tabular}




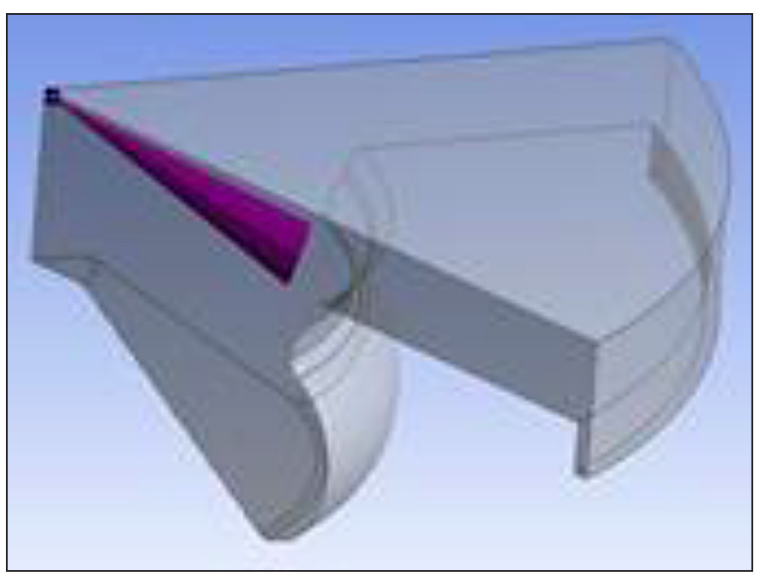

Fig. 1. 3D computational $60^{\circ}$ sector meshes. The number of computational cells was approx.19000

and combustion efficiency were also estimated. The engine specifications are presented in Table 3. The initial conditions of the simulation are illustrated in Table 4 and were kept constant during all tests. The engine model was validated using the experimental data from Cha et al. [17]. The data showed a good agreement which means that the simulation model works properly. The main submodels incorporated in the simulation are briefly discussed below. In ANSYS Forte detailed autoignition kinetics is used for ignition. The critical temperature and size of the ignition kernel criteria are used in the model. First, the ignition kernel is initiated, then the flame propagation model is activated; this forms computational cells with temperatures greater than the critical temperature which are considered, actually, as ignition sites. The G-equation combustion is modeled according to the turbulent premixed combustion flamelet theory. This theory presents two regimes of interest: the corrugated flamelet regime and the thin reaction zone regime [24]. ANSYS Forte presents advanced models that include the simulation of multi-component fuel spray dynamics; in addition, it simulates the spray interactions with flowing multi-component gases. The model includes the following sub-processes: spray atomization, wall impingement, droplet vaporization, droplet collision and coalescence, droplet breakup, as well as nozzle flow. For droplet breakup, the Kelvin-Helmholtz / Rayleigh-Taylor (KH/RT) model is used. It is known that in-cylinder reacting flows are compressible and extremely turbulent in internal combustion (IC) engines. ANSYS Forte code currently includes the Reynolds Averaged Navier-Stokes (RANS) equations. Both advanced and standard $\mathrm{k}-\varepsilon$ model formulations are available [24].

\section{VALIDATION PROCEDURE}

A three dimensional CI engine model has been built using ANSYS Forte code. The model has been validated by comparing the simulation results with experimental data from Cha et al. [17]. The primary fuel $n$-heptane is used in the calculations as surrogate fuels for diesel. The comparison was done for neat diesel fuel. The diesel fuel was injected directly to the combustion chamber during the compression stroke. The injection timing is $20^{\circ} \mathrm{CA}$ before top dead center (BTDC). The total amount of the injected fuel was $10[\mathrm{mg}]$ and the engine speed was $1200[\mathrm{rpm}]$. All other engine operating conditions in the present paper and Cha et al. [17] are the same. The calculations started from (IVC) to (EVO). The simulation was carried out for a $60^{\circ}$ sector mesh of the combustion chamber to reduce the calculation time. Although the experiments and simulation were conducted without EGR, the initial conditions for the ANSYS Forte calculations were estimated using the built-in code within the software. In the present investigation, the initial conditions were calculated on the basis of the fuel/air ratios and equivalence ratio. The in-cylinder pressure

Table 3. Engine specifications

\begin{tabular}{|l|c|}
\hline Intake valve close [deg] & -90 \\
\hline Exhaust valve open [deg] & 140 \\
\hline Bore [mm] & 130 \\
\hline Stroke [mm] & 160 \\
\hline Engine speed [rpm] & 1300 \\
\hline No. of strokes & 4 \\
\hline Connecting rod length [mm] & 250 \\
\hline Start of injection 1 [deg] & -63 \\
\hline Duration of injection 1 [deg] & 5.4 \\
\hline Start of injection 2 [deg] & -30 \\
\hline Duration of injection 2 [deg] & 2.8 \\
\hline Total fuel mass (gasoline-diesel) [mg] & 130 \\
\hline
\end{tabular}

Table 4. Initial conditions

\begin{tabular}{|l|c|}
\hline Pressure [bar] & 3.1 \\
\hline Temperature [K] & 400 \\
\hline Turbulence intensity & 0.1 \\
\hline Turbulence length scale [cm] & 1 \\
\hline Initial engine swirl ratio & 0.6 \\
\hline Initial swirl profile factor & 3.11 \\
\hline Cylinder wall temperature [K] & 420 \\
\hline Cylinder head temperature [K] & 490 \\
\hline Piston surface temperature [K] & 490 \\
\hline
\end{tabular}


and heat release rate are compared for the experimental and simulation data. Figure 2 shows a good agreement between the proposed model and the experimental data presented in Cha et al. [17]. Hence, the proposed model is able to predict the engine performance and emissions for various gasoline/diesel ratios with sufficient accuracy.

\section{RESULTS AND DISCUSSION}

In this paper, the effect of adding gasoline to diesel fuel on performance and emissions of IC engine has been investigated using professional ANSYS Forte software. A gasoline port injection and diesel direction injection CI engine has been modeled. In the simulation, the gasoline/ diesel $(\mathrm{G} / \mathrm{D})$ ratio was varied from $(50-80 \%)$ by volume. The cylinder pressure, temperature, heat release rate, power, thermal efficiency, combustion efficiency, NOx, CO, and unburned hydrocarbons were calculated and compared with neat diesel fuel for all gasoline/diesel ratios. The effect of $(G / D)$ ratios on the heat release rate is shown in Figure 3. The heat release rate increased when gasoline is added to diesel fuel. The maximum heat release rate occurs with gasoline ratio (50$60 \%)$ in the total fuel. Further increase of gasoline amount will decrease the heat release rate. When the G/D ratio increases, the first combustion stage drop while the second stage improves; this is due to the increase in ignition delay which cause an increase of mixing time [18]. Moreover, the addition of gasoline to the mixture with amount more than $60 \%$ (by volume) will increase the combustion duration as shown in Figure 4 and consequently expanding the combustion process to expansion stroke, resulting in increased engine losses and incomplete combustion. In addition, when the gasoline percentage is increased over $60 \%$ by volume, this could lead to a dramatic increase in the combustion durations resulting in a reduction in the combustion rate and a reduction in the peak pressure rising rate [19].

Figure 5 shows that the peak cylinder pressure increases when the gasoline amount added to diesel is between $50-60 \%$ by volume. A further increase of gasoline quantity will decrease the cylinder peak pressure. When the two-stage diesel injection technique is used, low temperature combustion and high temperature combustion (main combustion phase) will occur in the cylinder respectively, as shown in the heat release diagram

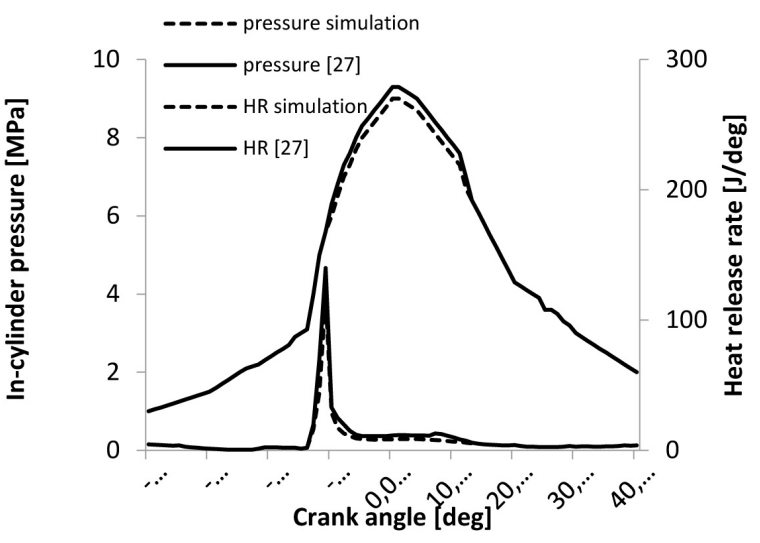

Fig. 2. The cylinder pressure and heat release rate for the simulation and experimental data [17]

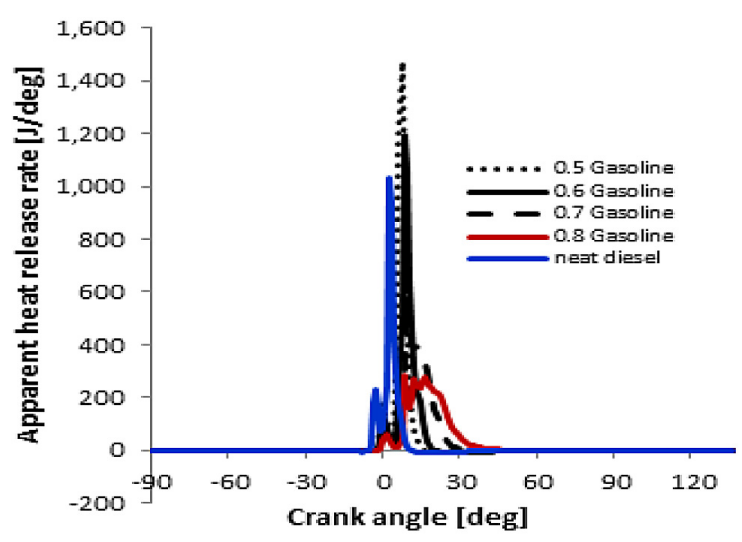

Fig. 3. Heat release rate versus G/D ratio

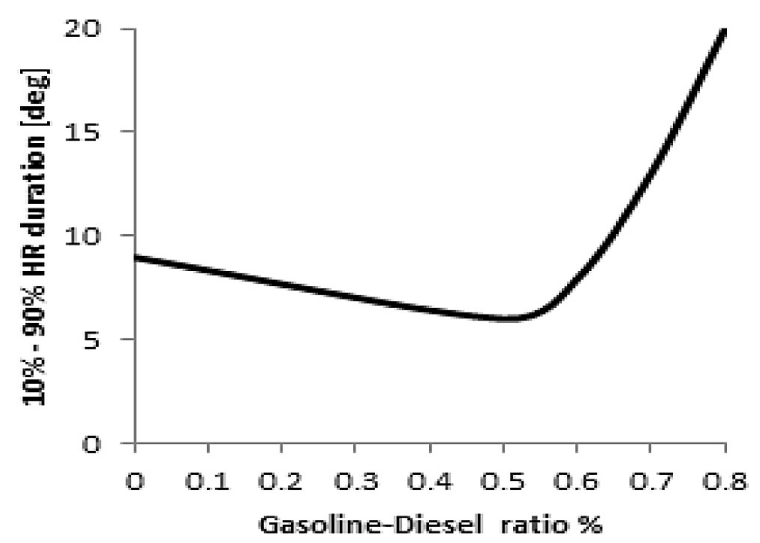

Fig. 4. Heat release duration versus G/D ratio

(Fig. 3) and the peak cylinder pressure diagram (Fig. 5). The use of high n-heptane proportion fuels results in shortening the distance between the two combustion stages, causing them to be close to each other. On the other hand, the use of high gasoline proportion fuels causes the two combustion stages to be more separate. In addition, 
increasing the gasoline proportion in the mixture to more than $60 \%$ causes a retard in the phasing and leads to a reduction in the peak cylinder pressure; besides, it causes a reduction in the maximum pressure rise rate for the two combustion stages, as well as an increase of the ignition delays. Moreover, there is a dramatic increase in the combustion duration when gasoline proportion increases; as shown in Figure 4. The same results have been obtained by Han et al. [19]. The start of combustion is delayed when gasoline is added to the diesel for all (G/D) ratios; this is caused by the higher auto-ignition temperature for gasoline fuel compared to diesel fuel. In addition, the major heat release period will extend to the power stroke and the combustion will not occur near top center with constant volume which will decrease the engine efficiency [19]. Adding more than $60 \%$ gasoline will increase the combustion duration and decrease the engine performance. The accumulated heat release rate is depicted in Figure 6 which shows that the heat release value is higher when gasoline is added to diesel for all (G/D) ratios. The greater heat release during premixed combustion increased the cylinder temperature. Furthermore, shifting the combustion closer to top dead center results in an increase in combustion temperature, as shown in Figure 7 [17].

The engine output power is maximal for (G/D) ratio between 50-60\%, as evident from Fig. 8(a). This is due to the higher total heat release rate and higher cylinder pressure as presented in Fig. 8(b). The effect of adding gasoline on combustion efficiency and engine thermal efficiency is shown in Figs. 8(c) and 8(d). The gasoline injection to the intake port increases the homogeneity of the fuel/ air mixture resulting in an improved combustion efficiency. Furthermore, the combustion process is closer to a constant volume combustion, resulting in a reduction of engine losses and an increase in the engine thermal efficiency. As mentioned earlier, the heat release rate duration is lower for $50-60 \%(\mathrm{G} / \mathrm{D})$ ratio, resulting in a higher flame speed and, subsequently, better combustion efficiency. The effect of gasoline addition to diesel fuel on engine emissions is illustrated in Fig. 9(a). The NO emission decreased when the gasoline amount increased in the fuel mixture. However, the amount of gasoline added to the mixture, the diesel injection timing, the engine load and speed should be optimized to gain the maximum benefit from RCCI technique, compared to neat diesel fuel operation. As seen in the Figure 6,

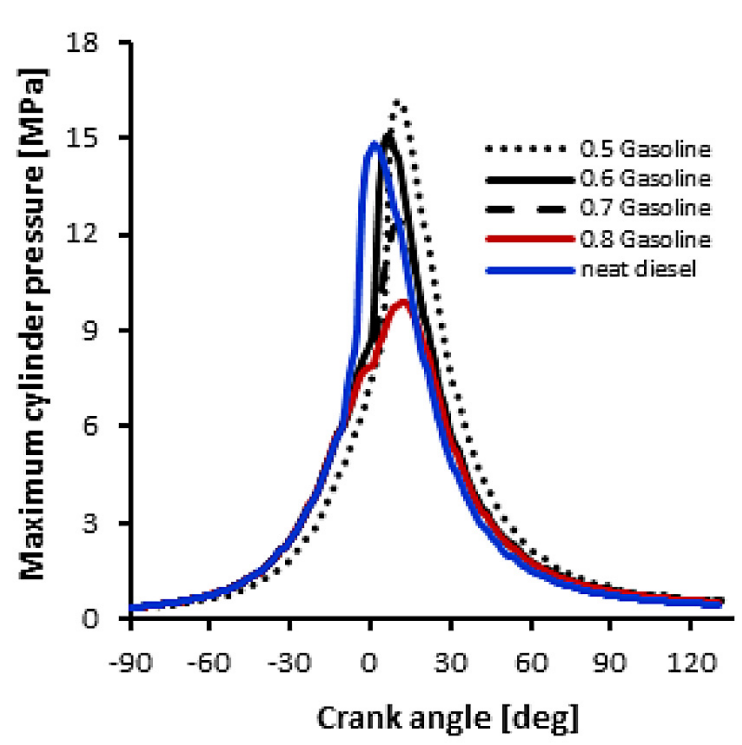

Fig. 5. Cylinder pressure versus G/D ratio

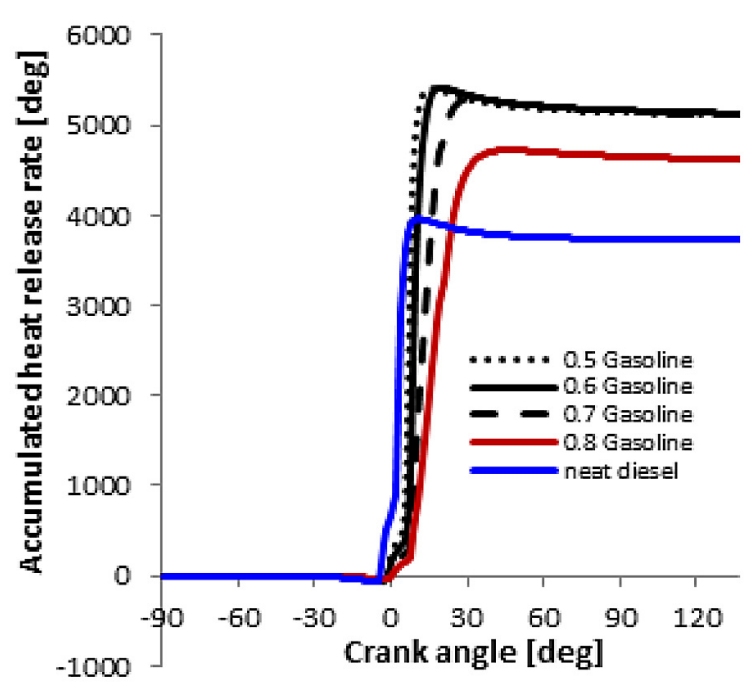

Fig. 6. Accumulated heat rate versus G/D ratio.

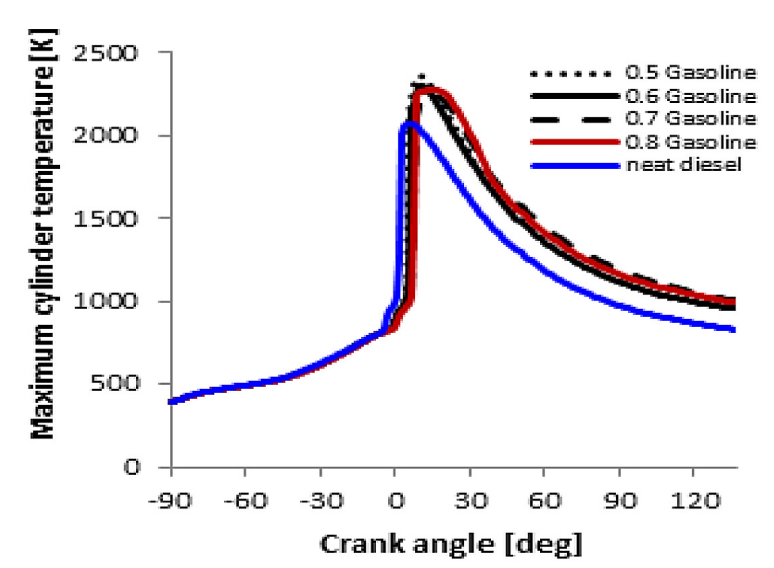

Fig. 7. In-cylinder temperature versus G/D ratio. 


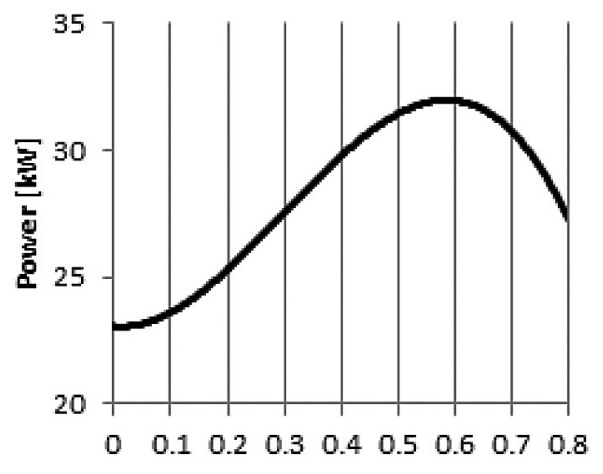

(a) Gasoline-Diesel ratio \%

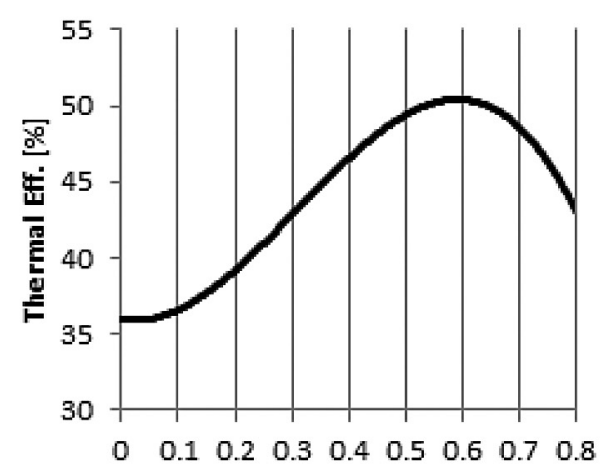

(c) Gasoline-Diesel ratio \%

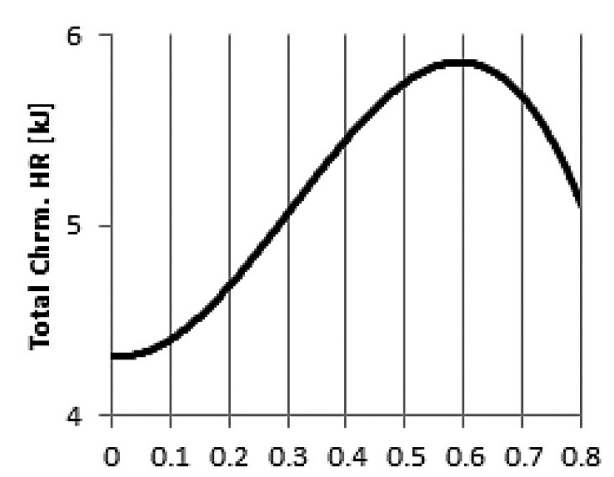

(b) Gasoline-Diesel ratio \%

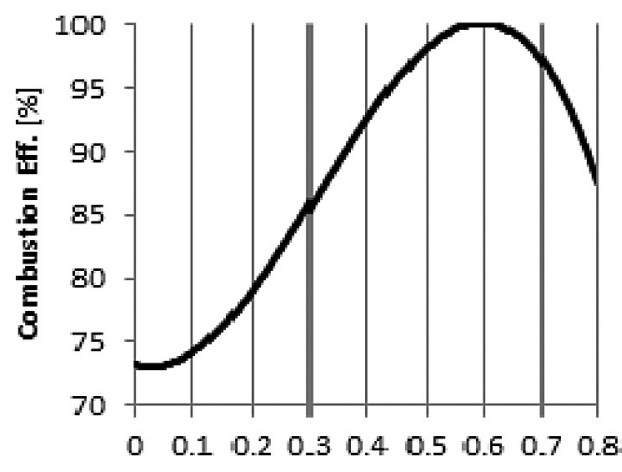

(d) Gasoline-Diesel ratio $\%$

Fig. 8. Engine power, total chemical HR, thermal efficiency, and combustion efficiency versus $\mathrm{G} / \mathrm{D}$ ratio

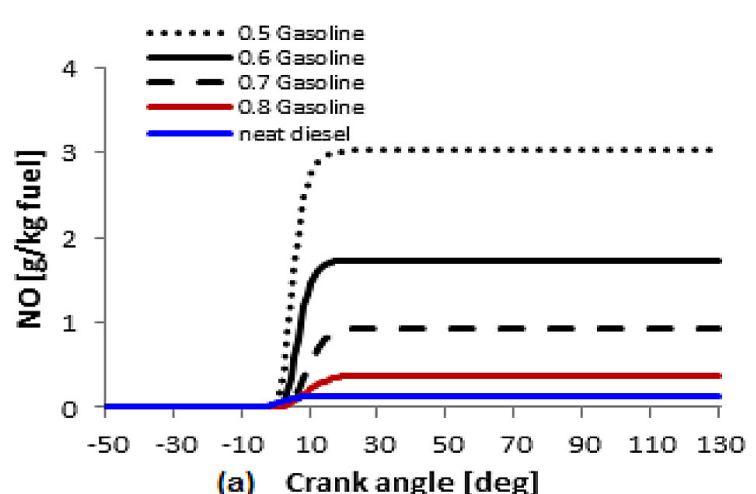

(a) Crank angle [deg]

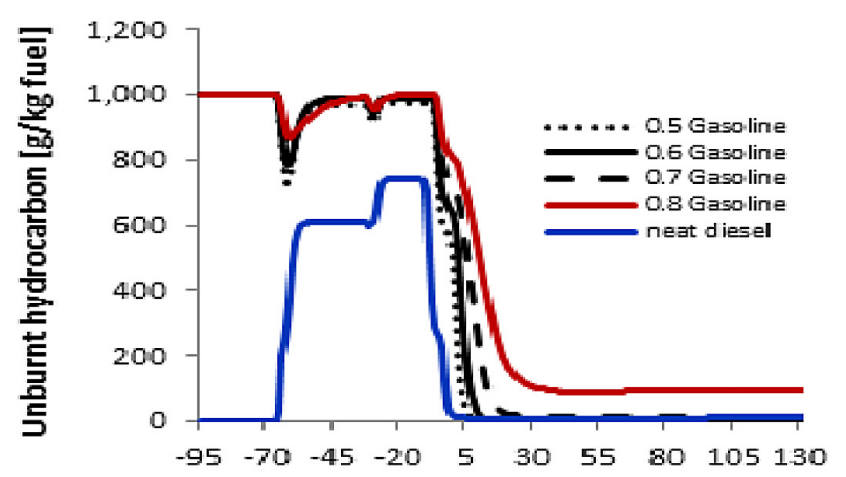

(c) Crank angle: [deg]

Fig. 9. Engine emissions versus G/D ratio

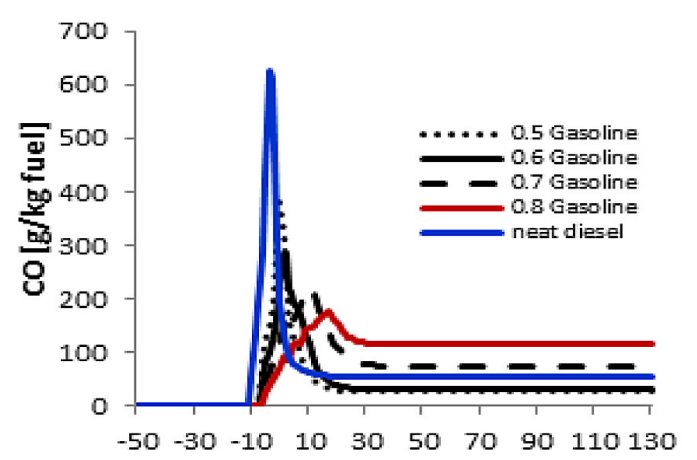

(b) Crank angle [deg] 
the in-cylinder temperature is higher when using gasoline-diesel mixture. Moreover, high oxygen and nitrogen concentration in the hot zone are major factors affecting the NO formation. Fig. 8 shows that when gasoline is added to diesel, hot zones inside the combustion chamber are seen, resulting in higher NO emission. Fig. 9(b) depicts the amount of $\mathrm{CO}$ fraction in the exhaust gases. Adding gasoline to the fuel mixture will decrease the $\mathrm{CO}$ emission. The enhanced combustion efficiency and the complete combustion due to the $50 \%-60 \%$ gasoline addition to the fuel mixture, as mentioned earlier, confirm the reduction in $\mathrm{CO}$ emissions compared to neat diesel fuel. In addition, lower $\mathrm{CO}$ and $\mathrm{HC}$ emissions also results from the high cylinder temperature which improves the $\mathrm{CO}$ and $\mathrm{HC}$ oxidation processes [18]. Moreover, multiple injections help reducing $\mathrm{HC}$ and $\mathrm{CO}$ emissions because the ignition delay between the start of the main injection and combustion is decreased [20]. Fig. 9(c) shows the un-burnt hydrocarbon amount versus (G/D) ratio; it shows that when increasing gasoline ratio in the mixture, the un-burnt hydrocarbon fraction formed near the cylinder wall increases which results in an incomplete combustion. The same results have been confirmed by Micklow et al. [5] and Yang et al. [22]. Additionally, the proposed model confirms that $n$-heptane, the most-reactive fuel component, burns at a faster rate compared to iso-octane which is less-reactive [15]. Adding gasoline fraction above $60 \%$ slows down the progress of combustion process which increases the heat release duration. This causes the combustion process to expand toward the power stroke which causes incomplete combustion, and consequently emitting high amounts of $\mathrm{HC}$ and $\mathrm{CO}$ [15]. Moreover, the existence of high amounts of low reactivity fuel across the cylinder and especially at cold regions (gasoline near the wall and the crevices, where it is difficult for the fuel to burn) has a stronger effect than the oxidation processes enhancement [25].

\section{CONCLUSIONS}

In this paper, a single cylinder CI engine has been modeled. The effect of adding gasoline to diesel fuel has been investigated using CFD ANSYS Forte professional software. The gasoline ratio in the fuel mixture varies from $50 \%$ to $80 \%$ by volume. The multiple injection technique is adopted in the simulation. The results show that improvement of the IC engine performance using dual fuel with different reactivity, such as gasoline and diesel, represents a promising technique for controlling the combustion characteristic and engine performance. The main conclusions can be summarized as follows:

1. Heat release rate increased $(40 \%)$ and cylinder pressure raised (around 13\%) compared to the neat diesel fuel, when the amount of the added gasoline varies from $(50-60 \%)$ of the total injected fuels. Further addition of gasoline negatively affects the engine performance.

2 . The combustion duration is extended drastically when the gasoline ratio is higher than $(60 \%)$

3. The $\mathrm{CO}$ and $\mathrm{HC}$ emissions increased and the NO amount decreased when the gasoline proportion increased in the mixture.

4. Adding (60\%) gasoline to the fuel mixture increases engine power (37\%), thermal efficiency (39\%) and combustion efficiency (35\%) compared to neat diesel fuel.

5. The two-stage injection can reduce the NOx emissions compared to a single injection DI diesel engine when the injection timing of the first and main injections is optimized.

The amount of the injected fuel and the injection timing should be optimized according to engine load, speed and initial conditions to gain the maximum benefits from this technique. In addition, by using CFD simulation detail information can be obtained about the complex phenomena which occur inside the combustion chamber and the interaction effects between these phenomena. This would allow the control of the combustion process by adjusting and optimizing the engine operating parameters.

\section{REFERENCES}

1. ANSYS Forte 17.0, ANSYS: San Diego, 2015.

2. Benajes J, Molina S, Garcia A, Belarte E, Vanvolsem M. 2014. An investigation on RCCI combustion in a heavy duty diesel engine using in-cylinder blending of diesel and gasoline fuels. Applied Thermal Engineering, (63), 66-76.

3. Cha J, Kwon S, Park S. 2011. An experimental and modelling study of the combustion and emission characteristics for gasoline-diesel dual-fuel engines. Proceedings of the Institution of Mechanical Engineers, Part D: Journal of Automobile Engineering, (225), 801-810. 
4. Chen G, Shen Y, Zhang Q, Yao M, Zheng Z, Liu H. Experimental study on combustion and emission characteristics of a diesel engine fueled with 2,5-dimethylfuran-diesel, n-butanol-diesel and gasoline-diesel blends. Energy 54 (2013) 333-342.

5. Chen Huang, Mingfa Yao, Xingcai Lu, Zhen Huang. 2009. Study of dimethyl ether homogeneous charge compression ignition combustion process using a multi-dimensional computational fluid dynamics model. International Journal of Thermal Sciences, (48), 1814-1822.

6. Ghazal O. Performance and combustion characteristic of CI engine fueled with hydrogen enriched diesel. Int. J. hydrogen energy 38 (2013) 15469-15476.

7. Han D, Guang H, Yang Z, Lu X, Huang Z. 2013. Premixed ignition characteristics of blends of gasoline and diesel-like fuels on a rapid compression machine. Thermal Science, (17), 1-10.

8. Junjun Ma, Xingcai Lü, Libin Ji, Zhen Huang. 2008. An experimental study of HCCI-DI combustion and emissions in a diesel engine with dual fuel. International Journal of Thermal Sciences (47) 1235-1242.

9. Kim DS, Kim MU, Lee CS. 2007. Combustion and emission characteristics of a partial homogeneous charge compression ignition engine when using two-stage injection. Combustion Science and Technology 179531-551.

10. Kim DS, Kim MU, Lee CS. Effect of premixed gasoline fuel on the combustion characteristics of compression ignition engine. Energy \& Fuels 18 (2004) 1213-1219.

11. Lopez JJ, Novella R, Garcia A, Winklinger JF. Investigation of the ignition and combustion processes of a dual-fuel spray under diesel-like conditions using computational fluid dynamics (CFD) modeling. Mathematical and Computer Modelling (57) 2013 1897-1906.

12. Mattarelli E, Rinaldini CA, Golovitchev V. 2014. CFD-3D analysis of a light duty Dual Fuel (Diesel/ Natural Gas) combustion engine. Energy Procedia, (45), 929-937.

13. Micklow GJ, Gong W. 2002. Mechanism of hydrocarbon reduction using multiple injection in a natural gas fuelled/micro-pilot diesel ignition engine. Int. J. of Engine Research, (3), 13-20.

14. Miller Jothi N.K., G. Nagarajan, S. Renganarayanan. 2008. LPG fueled diesel engine using diethyl ether with exhaust gas recirculation. Int. Journal of Thermal Sciences (47), 450-457.

15. Mousavi SM, Saray RK, Poorghasemi K, Magh- bouli A. A numerical investigation on combustion and emission characteristics of a dual fuel engine at part load condition. Fuel 166 (2016) 309-319.

16. Papagiannakis RG, Hountalas DT, Rakopoulos CD. 2007. Theoretical study of the effects of pilot fuel quantity and its injection timing on the performance and emissions of a dual fuel diesel engine. Energy Conversion and Management (48) 2951-2961. DOI:10.1016/j.enconman.2007.07.003

17. Park SH, Youn IM, Lim Y, Lee CS. 2013. Influence of the mixture of gasoline and diesel fuels on droplet atomization, combustion, and exhaust emission characteristics in a compression ignition engine. Fuel Processing Technology, (106), 392-401.

18. Puduppakkam KV, Liang L, Naik CV, Meeks E, Kokjohn SL, Reitz RD. Use of detailed kinetics and advanced chemistry-solution techniques in CFD to investigate dual-fuel engine concepts. SAE International (2011) 2011-01-0895

19. Rajendra Prasath B., P. Tamilporai, Mohd.F. Shabir. 2010. Analysis of combustion, performance and emission characteristics of low heat rejection engine using biodiesel. International Journal of Thermal Sciences, (49), 2483-2490.

20. Sezer I. Thermodynamic, performance and emission investigation of a diesel engine running on dimethyl ether and diethyl ether. Int. Journal of Thermal Sciences 50 (2011) 1594-1603

21. Splitter D, Wissink M, Kokjohn S, Reitz R. 2012. Effect of compression ratio and piston geometry on RCCI load limits and efficiency, SAE Int. J. Engines 2012-01-0383.

22. Won HW, Heinz P, Tait N, Kalghatgi G. 2012. Some effects of gasoline and diesel mixtures on partially premixed combustion and comparison with the practical fuels gasoline and diesel in a compression ignition engine. Proceedings of the Institution of Mechanical Engineers, Part D: Journal of Automobile Engineering, (226). 1259.

23. Yang, B., Li, S., Zheng, Z., Yao, M. et al., "A Comparative Study on Different Dual-Fuel Combustion Modes Fuelled with Gasoline and Diesel," SAE Technical Paper 2012-01-0694, 2012, doi: 10.4271/2012-01-0694.

24. Yokota H, Kudo Y, Nakajima H, Kakegawa T. A new concept for low emission diesel combustion. SAE Paper 970891

25. Zhang, J. Effects of intake air temperature on homogenous charge compression ignition combustion and emissions with gasoline and n-heptane. Thermal Science 19 (2015) 1897-1906. DOI: 10.2298/TSCI140524174. 